\title{
EKSISTENSI BAHASA DALAM IKLAN TELEVISI INDONESIA
}

\author{
Zamzani, Yayuk Eni Rahayu, dan Siti Maslakhah \\ Fakultas Bahasa dan Seni Universitas Negeri Yogyakarta \\ email: zamzani@uny.ac.id
}

\begin{abstract}
Abstrak
Penelitian ini bertujuan mendeskripsikan bahasa, bentuk lingual, dan keterkaitannya dengan sasaran dan jenis iklan di televisi. Sumber data adalah wacana iklan di televisi. Pengumpulan data dengan observasi dan pencatatan. Analisis data melalui proses pengorganisasian dan kategorisasi menggunakan padan bahasa dan padan pragmatik. Hasil penelitian sebagai berikut. Pertama, bahasa yang digunakan adalah Indonesia dan Inggris. Kedua, bentuk lingual berupa: kalimat bahasa Indonesia, kalimat bahasa Inggris, frase bahasa Inggris, dan kata bahasa Inggris. Ketiga, bahasa Indonesia dan campuran bahasa Indonesia-Inggris digunakan untuk sasaran sosial dan usia umum, sedangkan bahasa Inggris untuk sasaran kelas sosial tinggi dan usia muda. Kempat, bahasa Indonesia digunakan pada iklan produk/jasa pada umumnya, sedangkan bahasa Inggris digunakan pada iklan produk/jasa "mewah" dengan sasaran sosial tinggi dan usia muda. Kelima, kalimat bahasa Indonesia digunakan pada iklan dengan sasaran umum, baik dilihat dari kelas sosial maupun usia, sedangkan kalimat bahasa Inggris digunakan dalam iklan dengan sasaran kelas sosial tinggi dan usia muda.
\end{abstract}

Kata kunci: penggunaan bahasa, bentuk lingual, kelas sosial, dan iklan

\section{LANGUAGES IN TELEVISION ADVERTISEMENTS IN INDONESIA}

\begin{abstract}
This study aims to describe languages, lingual forms, and their relevance to the targets and types of advertisements on television. The data sources were advertisements on television. The data were collected through observations and recording. They were analyzed by organizing and categorizing them through language and pragmatic correspondences. The findings are as follows. First, the languages used are Indonesian and English. Second, the lingual forms include Indonesian sentences, English sentences, English phrases, and English words. Third, Indonesian and Indonesian-English mixes are used for the target with the social class and age on average, while English is for the high social class and youth. Fourth, Indonesian is used in product/service advertisements in general, while English is used in "luxury" product/service advertisements for the target with the high social class and young age. Fifth, Indonesian sentences are used in advertisements for the general target in terms of the social class and age, whereas English sentences are used in advertisements for the target with the high social class and young age.
\end{abstract}

Keywords: use of languages, lingual forms, social class, advertisements

\section{PENDAHULUAN}

Bahasa Indonesia berkedudukan sebagai bahasa nasional (bahasa persatuan) tercantum dalam Sumpah Pemuda 28
Oktober 1928, dan sebagai bahasa negara tercantum dalam UUD 1945, Bab XV, pasal 36. Fungsi dan kedudukan bahasa Indonesia secara politis telah jelas, baik 
dalam kedudukannya sebagai bahasa negara, bahasa resmi nasional maupun sebagai bahasa persatuan (lihat UURI Nomor 24 Tahun 2009; Alwi dan Sugono, 2011). Selain fungsi dan kedudukan bahasa Indonesia dalam perspektif politik bahasa nasional Indonesia, terdapat pula fungsi dan kedudukan bahasa daerah dan bahasa asing. Hal ini merupakan suatu keniscayaan karena bangsa Indonesia memang hidup berdampingan dengan bangsa-bangsa lain sehingga politik bahasa nasional berkaitan dengan permasalahan fungsi dan kedudukan bahasa asing di Indonesia. Sementara itu, bangsa yang majemuk dilihat dari sisi etnik dan bahasa berkonsekuensi politik bahasa nasional mau tidak mau berkaitan dengan fungsi dan kedudukan bahasa daerah.

Dalam perspektif tribahasa di Indonesia tersebut, yaitu bahasa Indonesia, bahasa daerah, dan bahasa asing, posisi bahasa Indonesia dipandang pada posisi di tengah. Dengan demikian, secara berturutan posisinya adalah bahasa asing, bahasa Indonesia, bahasa daerah (Setyaningrum, 2014: 241). Hal itu didukung pula bahwa sumbangan kosa kata atau leksikon bahasa Indonesia ternyata paling banyak dari bahasa asing, bahasa daerah, baru dari bahasa Melayu. Hal ini tentu saja berangkat dari perspetif bahwa "induk" bahasa Indonesia adalah bahasa Melayu. Meski demikian, harus disadari bahwa Indonesia telah mengupayakan politik bahasa yang tegas dan jelas dengan menerbitkan UU yang terkait dengan kedudukan dan fungsi bahasa tersebut: kapan bahasa Indonesia, daerah, dan asing digunakan. Persoalan berikutnya benarkah kebijakan politik bahasa tersebut telah dapat dilaksanakan dengan konsistensi yang baik oleh masyarakat dalam era global ini.

Dalam era globalisasi tidak berarti aspek kehidupan manusia baik bidang ekonomi, politik, maupun kebudayaan akan secara otomatis menjadi homogen.
Justru pada era globalisasi tersebut kekhususan suatu bangsa semakin tampak (atau ditampakkan?). Hal itu tampak dari adanya penegasan tentang kemerdekaan, atau kedaulatan suatu bangsa. Salah satu kekhususan yang terdapat pada identitas bangsa adalah bahasa, bahasa dijadikan jati diri bangsa, kebanggaan nasional (lihat UURI Nomor 24 Tahun 2009). Pertanyaan yang muncul, bagaimanakah kondisi itu dengan kekhususan bangsa Indonesia dengan bahasa Indonesia? Bukankah dalam konteks yang demikian justru peluang terjadinya "persaingan bahasa" juga semakin terbuka. Hal itu berarti pula persoalan kontak bahasa menjadi sebuah keniscayaan.

Atas dasar pemikiran yang demikian itulah penelitian ini dirancang untuk dilaksanakan guna mendapatkan informasi yang aktual tentang pemakaian bahasa dalam kaitannya dengan kontak bahasa yang merupakan keniscyaan dalam bilingualisme atau multilingualisme dalam masyarakat multilingual tersebut. Penelitian ini tentu saja diharapkan dapat memenuhi keutamaan penelitian yang berupa menemukan fakta empirik tentang perilaku pemakaian bahasa dengan fokus penggunaan bahasa dan bentuk lingual dalam iklan televisi Indonesia, katerkaitan penggunaan bahasa, bentuk lingual dalam iklan televisi dengan sasaran iklan dan jenis iklan.

Kondisi kebahasaan bahasa Indonesia yang sangat terbuka terhadap bahasa asing memiliki sisi positif dan negatif pada masyarakat tutur bahasa Indonesia. Hal itu dapat dimengerti karena kenyataan bahasa Indonesia dan masyarakat Indonesia tidak dapat lepas dari pergaulan dunia di era global ini. Konsekuensi dari era ini adalah terjadinya kontak bahasa. Kontak bahasa dapat dimaknai sebagai pemakaian dua bahasa atau lebih dalam waktu dan tempat yang sama. Bidang ilmu yang meneliti kontak bahasa disebut linguistik kontak atau contact linguistics (Thomason, 
2001: 1). Sekarang telah berkembang pesat studi kontak bahasa tersebut seperti di Glandon College, New York University dengan label Center for Research on Language and Culture Contact hingga ada jurnal yang khusus memuat kajian kontak bahasa, yaitu Journal of Language Contact. Dalam konteks yang demikian penutur yang berbeda bahasa melakukan interaksi, yang berarti terjadi kontak bahasa, akan berpeluang bahasa-bahasa yang mengalami kontak bahasa itu terjadi saling mempengaruhi (Matras, 2009).

Adapun akibat dari adanya kontak bahasa tersebut banyak sekali, dari terjadinya peminjaman kosa kata, campur kode, alih kode, pidgin, kepunahan bahasa, sampai adanya pembentukan bahasa baru yang biasa disebut bahasa kreol (creol) (lihat Thomason, 2001; Matras, 2009; Hickey, 2013). Manifestasi kontak bahasa terdapat banyak variasi ranah, dari ranah pemerolehan bahasa, proses dan produksi bahasa, fungsi sosial bahasa, politik atau kebijakan bahasa, tipologi dan perubahahan bahasa, pergeseran bahasa, pemertahanan bahasa, sampai pada kepunahan bahasa. Kajian kontak bahasa dapat dilakukan secara sinkronik dengan melihat aspek bilingual atau multilingual dan secara diakronik dengan melihat terjadinya perubahan bahasa (Matras, 2009: 1-2). Kajian sinkronik dapat dilihat pada kaitan antara kontak bahasa dengan aspek-aspek gramatika dan leksikon (Hickey, 2013). Winford (Matras, 2003) telah melakukan kajian kontak bahasa dengan perspektif bahasa sebagai aktivitas sosial dan komunikasi sebagai alat untuk mencapai tujuan. Ia berkesimpulan bahwa dari sisi penutur sebagai aktor yang menggunakan bahasa untuk mencapai tujuan. Untuk mencapai tujuan tersebut dapat dipilih bahasa: yang meliputi struktur, bentuk kata, intonasi, dan sebagainya. Sementara itu, dari sisi mitra tutur dapat dianalisis kategori linguistiknya. Kontak bahasa sebagai bagian dari aktivitas sosial selalu terkait dengan konteks: fungsi dan situasi tertentu.
Inilah pentingnya mengaitkan bahasa dengan masyarakat karena kegiatan berbahasa sebagai bagian dari aktivitas sosial suatu masyarakat. Bahasa menggambarkan suatu masyarakat/komunitas. Setiap orang sebagai anggota komunitas suatu masyarakat dipastikan dalam bahasa yang sama. Bahasa sebagai imajiner dunia tentang suatu masyarakat (Hudson, 2000: 5-6). Bahasa dan masyarakat memiliki peluang keterkaitan: struktur bahasa mempengaruhi struktur masyarakat, struktur masyarakat mempengaruhi struktur bahasa, struktur bahasa dan struktur masyarakat saling mempengaruhi, dan struktur bahasa dan struktur masyarakat saling berhubungan tetapi satu sama lain saling indipenden (Watdhaugh, 1998: 10-11).

Akibat dari kontak bahasa yang beraneka tersebut sangat bergantung rentang waktu (lamanya) terjadinya kontak bahasa. Dalam hal ini terdapat dinamika kontak bahasa, setidaknya ada dua, yaitu (1) untuk mencapai tujuan yang berupa efisiensi komunikasi terjadi konflik kekuatan yang berupa kebutuhan, dan (2) untuk tujuan interaksi terjadi penekanan identitas perasaan grup atau loyalitas grup (Matras, 2009). Dalam konteks yang terakhir ini yakni terkait dengan pesoalan perasaan grup atau loyalitas grup akan terkait dengan persoalan gengsi atau prestise. Oleh karenanya, dapat dimaklumi bila Moeliono (2011: 135) mengungkap pentingnya perencanaan gengsi atau prestise.

Bila konsep ini dikenakan pada multilingual masyarakat Indonesia antara lain dapat digambarkan sebagai berikut. Pencampuran bahasa (campur kode) telah terjadi pada sebagian penutur Indonesia (Chaer dan Agustina, 2010: 160), campur kode dan alih kode (Silado, 2011; Haryanto, 2014). Banyak orang Indonesia yang belajar dan menguasai bahasa asing dengan baik, tetapi bahasa Indonesia seadanya; begitu menghargai bahasa asing secara 
berlebihan, dan suka menggunakan istilah asing meski ada istilahnya dalam bahasa Indonesia (Muslih, 2010:39). Penutur yang memiliki sikap positif tentu tidak melakukan hal yang demikian, tetapi kebanyakan orang Indonesia belum memiliki sikap positif (Chaer dan Agustina, 2010: 160, lihat pula Sudaryanto, 2016). Sikap positif memiliki ciri (1) kesetiaan bahasa, kebanggan bahasa, dan (2) kesadaran akan adanya norma bahasa. Posisi bahasa Indonesia secara emosi dan keakraban berada di nomor dua setelah bahasa daerah, dan bagi sebagian yang lain berada di bawah bahasa asing, yaitu bahasa Inggris (Chaer dan Agustina, 2010: 150-152). Dari sisi perspektif tribahasa, secara berturutan posisinya adalah bahasa asing, bahasa Indonesia, bahasa daerah (Setyaningrum, 2014: 241). Dalam kondisi yang demikian ini diperlukan reaktualisasi peran bahasa Indonesia dalam konteks lokal dan global (Widada, 2011).

Kebijakan kebahasaan di Indonesia terkait dengan penggunaan bahasa selalu berhubungan dengan kedudukan dan fungsi bahasa. Hal tersebut tentu saja berhubungan erat dengan politik bahasa. Politik bahasa di Indonesia sering disebut dengan istilah politik bahasa nasional yang juga disebut dengan kebijakan bahasa nasional. Kebijakan bahasa nasional merupakan kebijakan nasional yang berisi pengarahan, perencanaan, dan ketentuanketentuan yang dapat dipakai sebagai dasar pengelolaan masalah kebahasaan dan kesastraan di Indonesia. Pembicaraan politik bahasa terkait persoalan tribahasa yang saling terkait, yaitu (1) masalah bahasa Indonesia, (2) masalah bahasa daerah, dan (3) masalah bahasa asing seperti yang telah diungkapkan di atas (lihat pula Alwi dan Sugono, 2011: 3). Dalam konteks yang demikian itu, diperlukan adanya satu kebijakan nasional yang benar-benar terencana, terarah, dan menyeluruh (Alwi dan Sugono, 2011: 3).
Kedudukan bahasa mengacu pada status relatif suatu bahasa sebagai suatu sistem lambang nilai budaya yang dirumuskan atas dasar nilai sosial yang berhubungan dengan bahasa yang bersangkutan. Hal tersebut dapat dimaknai jika yang dibicarakan kedudukan bahasa Indonesia, acuannya adalah status bahasa Indonesia sebagai lambang nilai budaya Indonesia yang dirumuskan atas dasar nilai sosial bahasa Indonesia. Dengan konsep tersebut, kedudukan bahasa Indonesia memiliki dua kedudukan (sesuai nilai sosial bahasa Indonesia) yaitu (1) sebagai bahasa resmi negara yang disebut juga bahasa negara, dan (2) sebagai bahasa persatuan yang disebut juga sebagai bahasa nasional atau bahasa kebangsaan (Alwi dan Sugono, 2011: 4-5, UURI Nomor 24 Tahun 2009 Pasal 25).

Fungsi bahasa bahasa mengacu pada konsep peran suatu bahasa di dalam masyarakat pemakainya. Fungsi bahasa selalu terkait dengan kedudukan bahasa itu sendiri. Fungsi bahasa berkaitan dengan kedudukan bahasa negara, nasional, bahasa daerah, dan bahasa asing. Bahasa daerah merupakan bahasa yang dipergunakan sebagai (1) bahasa perhubungan intradaerah atau intramasyarakat di samping bahasa Indonesia, dan (2) sarana pendukung sastra dan budaya daerah atau masyarakat etnik di wilayah Republik Indonesia. Bahasa asing di Indonesia mengacu pada semua bahasa, kecuali bahasa Indonesia, bahasa-bahsa daerah, dan bahasa serumpun Melayu (Alwi dan Sugono, 2011: 4).

Fungsi bahasa Indonesia sebagai bahasa nasional dapat meliputi fungsi sebagai (1) lambang kebanggaan nasional, (2) lambang identitas nasional, (3) alat pemersatu berbagai kelompok etnik yang berbeda latar belakang sosial budaya dan bahasanya, dan (4) alat penghubung antarbudaya serta antardaerah (Alwi dan Sugono, 2011: 5). Dengan konsep yang sama, keempat fungsi bahasa Indonesia 
sebagai bahasa nasional tersebut diungkapkan UURI Nomor 24 Tahun 2009 Pasal 25 Ayat (2) bahwa bahasa Indonesia berfungsi sebagai (1) jati diri bangsa, (2) kebanggaan nasional, (3) sarana pemersatu berbagai suku bangsa, serta (4) sarana komunikasi antardaerah dan antarbudaya daerah.

Bahasa Indonesia sebagai sebagai bahasa negara memiliki fungsi sebagai (1) bahasa resmi kenegaraan, (2) pengantar pendidikan, (3) komunikasi tingkat nasional, (4) pengembangan kebudayaan nasional, (5) transaksi dan dokumentasi niaga, dan (6) sarana pengembangan dan pemanfaatan ilmu pengetahuan, teknologi, seni, dan bahasa media massa (UURI Nomor 24 Tahun 2009).

\section{METODE}

Penelitian ini meupakan penelitian deskriptif kualitatif dengan dukungan kuantitatif. Subjek penelitian adalah wacana iklan televisi Indonesia selama tiga bulan, dengan teknik insidental diperoleh sebanyak 59 iklan dari berbagai siaran iklan televisi baik iklan produk maupun jasa. Objek penelitian ini adalah penggunaan bahasa dan bentuk lingual dengan lima fokus penelitian. Pengumpulan data dilakukan melalui observasi dan pencatatan. Instrumen pengumpul data berupa manusia dilengkapi dengan perangkat keras berupa alat rekam dan alat tulis. Analisis dilakukan melalui proses pengorganisasian dan kategorisasi menggunakan padan bahasa dan padan pragmatik. Padan bahasa digunakan untuk menentukan bentuk lingual dan status bahasa bentuk lingual. Padan pragmatik digunakan untuk mengaitkan antara bentuk lingual dengan jenis iklan dan sasaran iklan dengan dukungan konteks dan kinesik pelaku atau pemeran iklan.

\section{HASIL DAN PEMBAHASAN Hasil Penelitian}

Hasil penelitian ini terkait dengan lima tujuan penelitian dengan didahului penyajian subjek penelitian. Subjek atau sumber data penelitian berupa iklan yang dikumpulkan berjumlah 59 iklan. Dari sumber data iklan sejumlah itu dapat dikelompokkan menjadi iklan produk dan iklan jasa. Iklan produk dapat dikelompokkan lagi menjadi iklan mi instan, iklan sabun muka, iklan sabun mandi, iklan shampo, iklan minuman, iklan rokok, iklan makanan ringan, iklan pembersih pakaian, iklan mobil, iklan obat, dan iklan perumahan. Sementara itu, iklan jasa berupa iklan hotel, iklan travel, iklan makam, iklan pendidikan, iklan jasa pengiriman barang, dan iklan toko online (daring).

Bahasa yang digunakan dalam sumber data ini meliputi bahasa Indonesia dan bahasa Inggris. Penggunaan bahasa Indonesia semua berupa kalimat. Penggunaan kata daerah dalam iklan dipandang sebagai kata bahasa Indonesia. Nama barang atau produk diabaikan dari penjenisan bahasa. Penggunaan bahasa Inggris dalam iklan televisi yang terdapat dalam sumber data ditemukan berwujud kalimat, frasa, dan kata.

Penggunaan bahasa dan bentuk lingual terkait dengan jenis iklan dan sasaran (pangsa) iklan. Bahasa Indonesia digunakan hampir semua iklan televisi di Indonesia yang wujudnya berupa kalimat. Kalimat bahasa Inggris dipergunakan pada sebagian kecil jenis iklan, yaitu mobil dan rokok saja. Sebagian kecil menggunakan frasa berbahasa Inggris. Sebagian besar iklan menggunakan kosakata bahasa Inggris.

Berikut ini tabel hasil penelitian yang menunjukkan jenis dan subjek penelitian, sasaran iklan, bahasa yang meliputi nama bahasa dan bentuk-bentuk lingual yang dipakai dalam iklan televisi di Indonesia. Data kuantitatif disajikan pada bagian lampiran. 
Tabel 1. Jenis, Sasaran, dan Bahasa Iklan Televisi di Indonesia

\begin{tabular}{|c|c|c|c|c|c|c|c|c|c|c|c|}
\hline \multirow{3}{*}{$\begin{array}{l}\text { Jenis } \\
\text { Iklan } \\
\text { Produk }\end{array}$} & \multirow{3}{*}{ Subjek } & \multicolumn{5}{|c|}{ Sasaran Iklan } & \multicolumn{5}{|c|}{ Bahasa } \\
\hline & & \multicolumn{3}{|l|}{ Sosial } & \multicolumn{2}{|l|}{ Usia } & \multicolumn{2}{|l|}{ Indonesia } & \multicolumn{3}{|l|}{ Inggris } \\
\hline & & Tinggi & Rendah & Uтит Tиа & Muda Anak & Umum & Kallmat Frasa & Kata & Kalimat & Frasa & Kata \\
\hline \multirow[t]{5}{*}{$M i$} & Mi 1 & & & $v$ & & $v$ & $v$ & & & & $v$ \\
\hline & Mi 2 & & & $\mathrm{v}$ & & $\mathrm{v}$ & $\mathrm{v}$ & & & & \\
\hline & Mi 3 & & & $\mathrm{v}$ & & $\mathrm{v}$ & $\mathrm{v}$ & & & & \\
\hline & Mi 4 & & & $\mathrm{v}$ & & $\mathrm{v}$ & $\mathrm{v}$ & & & $\mathrm{v}$ & $\mathrm{v}$ \\
\hline & Mi 5 & & & $\mathrm{v}$ & & $\mathrm{v}$ & $\mathrm{v}$ & & & & \\
\hline \multirow{5}{*}{$\begin{array}{l}\text { Sabun } \\
\text { Muka }\end{array}$} & Mk 1 & & & $\mathrm{v}$ & $\mathrm{v}$ & & $\mathrm{v}$ & & & & $\mathrm{v}$ \\
\hline & Mk 2 & & & $\mathrm{v}$ & $\mathrm{v}$ & & $\mathrm{v}$ & & & & $\mathrm{v}$ \\
\hline & Mk 3 & & & $\mathrm{v}$ & $\mathrm{v}$ & & $\mathrm{v}$ & & & $\mathrm{v}$ & $\mathrm{v}$ \\
\hline & Mk 4 & & & $\mathrm{v}$ & $\mathrm{v}$ & & $\mathrm{v}$ & & & $\mathrm{v}$ & \\
\hline & Mk 5 & & & $\mathrm{v}$ & $\mathrm{v}$ & & $\mathrm{v}$ & & $\mathrm{v}$ & & $\mathrm{v}$ \\
\hline \multirow{5}{*}{$\begin{array}{l}\text { Sabun } \\
\text { Mandi }\end{array}$} & Md 1 & & & $\mathrm{v}$ & & $v$ & $\mathrm{v}$ & & & & \\
\hline & $\operatorname{Md} 2$ & & & $\mathrm{v}$ & & v & $\mathrm{v}$ & & & & \\
\hline & Md 3 & & & $\mathrm{v}$ & & $\mathrm{v}$ & $\mathrm{v}$ & & & & \\
\hline & $\operatorname{Md} 4$ & & & $\mathrm{v}$ & & $\mathrm{v}$ & $\mathrm{v}$ & & & & \\
\hline & Md 5 & & & $\mathrm{v}$ & & $\mathrm{v}$ & $\mathrm{v}$ & & & & \\
\hline \multirow{5}{*}{ Sampo } & Sp 1 & & & $\mathrm{v}$ & & $v$ & $\mathrm{v}$ & & & $\mathrm{v}$ & \\
\hline & Sp 2 & & & $\mathrm{v}$ & & $\mathrm{v}$ & $\mathrm{v}$ & & & $\mathrm{v}$ & \\
\hline & Sp 3 & & & $\mathrm{v}$ & & $\mathrm{v}$ & $\mathrm{v}$ & & & $\mathrm{v}$ & \\
\hline & Sp 4 & & & $\mathrm{v}$ & & v & $\mathrm{v}$ & & & $\mathrm{v}$ & \\
\hline & Sp 5 & & & $\mathrm{v}$ & & $\mathrm{v}$ & $\mathrm{v}$ & & & & \\
\hline \multirow{5}{*}{$\begin{array}{l}\text { Minum- } \\
\text { an }\end{array}$} & Mn 1 & & & $\mathrm{v}$ & & $v$ & $\mathrm{v}$ & & & & \\
\hline & Mn 2 & & & $\mathrm{v}$ & & $\mathrm{v}$ & $\mathrm{v}$ & & & $\mathrm{v}$ & \\
\hline & Mn 3 & & & $\mathrm{v}$ & & $\mathrm{v}$ & $\mathrm{v}$ & & & $\mathrm{v}$ & \\
\hline & $\operatorname{Mn} 4$ & & & $\mathrm{v}$ & & $\mathrm{v}$ & $\mathrm{v}$ & & & $\mathrm{v}$ & \\
\hline & Mn 5 & & & $\mathrm{v}$ & & $\mathrm{v}$ & $\mathrm{v}$ & & & & \\
\hline \multirow[t]{4}{*}{ Rokok } & Rk 1 & & & $\mathrm{v}$ & $\mathrm{v}$ & & $\mathrm{v}$ & & & & \\
\hline & Rk 2 & & & $\mathrm{v}$ & $\mathrm{v}$ & & $\mathrm{v}$ & & & & $\mathrm{v}$ \\
\hline & Rk 3 & $\mathrm{v}$ & & & $\mathrm{v}$ & & & & $\mathrm{v}$ & & \\
\hline & Rk 4 & & & $\mathrm{v}$ & $\mathrm{v}$ & & $\mathrm{v}$ & & & & \\
\hline Makanan & Mr 1 & & & $\mathrm{v}$ & & $\mathrm{v}$ & $\mathrm{v}$ & & & & \\
\hline \multirow[t]{4}{*}{ Ringan } & Mr 2 & & & $\mathrm{v}$ & & $\mathrm{v}$ & $\mathrm{v}$ & & & & \\
\hline & Mr 3 & & & $\mathrm{v}$ & & $\mathrm{v}$ & $\mathrm{v}$ & & & & \\
\hline & $\mathrm{Mr} 4$ & & & $\mathrm{v}$ & & $\mathrm{v}$ & $\mathrm{v}$ & & & & $\mathrm{v}$ \\
\hline & Mr 5 & & & $\mathrm{v}$ & & $\mathrm{v}$ & $\mathrm{v}$ & & & & \\
\hline \multirow{5}{*}{$\begin{array}{l}\text { Pem- } \\
\text { bersih } \\
\text { Pakaian }\end{array}$} & Bp 1 & & & $\mathrm{v}$ & & $\mathrm{v}$ & $\mathrm{v}$ & & & & $\mathrm{v}$ \\
\hline & Bp 2 & & & $\mathrm{v}$ & & $\mathrm{v}$ & $\mathrm{v}$ & & & & $\mathrm{v}$ \\
\hline & Bp 3 & & & $\mathrm{v}$ & & $\mathrm{v}$ & $\mathrm{v}$ & & & & \\
\hline & Bp 4 & & & $\mathrm{v}$ & & $\mathrm{v}$ & $\mathrm{v}$ & & & $\mathrm{v}$ & \\
\hline & Bp 5 & & & $\mathrm{v}$ & & $\mathrm{v}$ & $\mathrm{v}$ & & & & \\
\hline \multirow[t]{8}{*}{ Mobil } & $\mathrm{Mb} 1$ & $\mathrm{v}$ & & & & $\mathrm{v}$ & & & $\mathrm{v}$ & & \\
\hline & $\mathrm{Mb} 2$ & $\mathrm{v}$ & & & & $\mathrm{v}$ & & & $\mathrm{v}$ & & \\
\hline & $\mathrm{Mb} 3$ & $\mathrm{v}$ & & & & $\mathrm{v}$ & $\mathrm{v}$ & & $\mathrm{v}$ & & \\
\hline & $\mathrm{Mb} 4$ & $\mathrm{v}$ & & & & $\mathrm{v}$ & & & $\mathrm{v}$ & & \\
\hline & Mb 5 & $\mathrm{v}$ & & & & $\mathrm{v}$ & $\mathrm{v}$ & & $\mathrm{v}$ & & \\
\hline & $\mathrm{Mb} 6$ & $\mathrm{v}$ & & & & $\mathrm{v}$ & $\mathrm{v}$ & & $\mathrm{v}$ & & \\
\hline & $\mathrm{Ob} 1$ & & & $\mathrm{v}$ & & $\mathrm{v}$ & $\mathrm{v}$ & & & & \\
\hline & $\mathrm{Ob} 2$ & & & $\mathrm{v}$ & & $\mathrm{v}$ & $\mathrm{v}$ & & & & \\
\hline Obat & $\mathrm{Ob} 3$ & & & $\mathrm{v}$ & & $\mathrm{v}$ & $\mathrm{v}$ & & & & $\mathrm{v}$ \\
\hline & $\mathrm{Ob} 4$ & & & $\mathrm{v}$ & & $\mathrm{v}$ & $\mathrm{v}$ & & & & $\mathrm{v}$ \\
\hline & $\mathrm{Ob} 5$ & & & $\mathrm{v}$ & & $\mathrm{v}$ & $\mathrm{V}$ & & & & \\
\hline
\end{tabular}




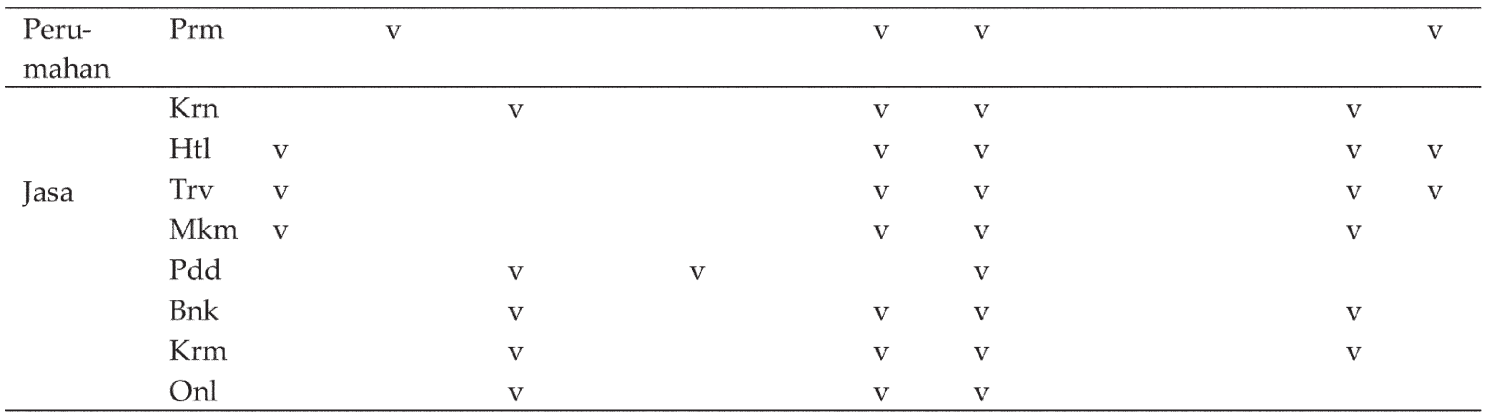

Keterangan:

$\mathrm{Bp}=$ pembersih pakaian

$\mathrm{Mb}=$ mobil

Bnk = bank

$\mathrm{Mkm}=$ makam

$\mathrm{Rk}=$ rokok

\section{Pembahasan}

Bahasa yang Digunakan dalam Iklan Televisi di Indonesia

Iklan di televisi Indonesia menggunakan bahasa Indonesia dan bahasa Inggris. Penggunaan unsur bahasa daerah yang berupa kata atau logat/dialek (Jawa, Jakarta, Makasar) dalam penelitian ini dipandang sebagai bahasa Indonesia karena secara subtansi yang digunakan dalam iklan bahasa Indonesia. Dengan demikian, pada umumnya bahasa Indonesialah yang dipakai dalam iklan tersebut. Dari seluruh iklan yang digunakan sebagai sumber data hampir seluruhnya menggunakan bahasa Indonesia sebagai bahasa pokoknya, setidaknya yang muncul pada tulisan. Hal ini dapat dipahami posisi bahasa daerah sebagai sebagai pendukung dan pemerkaya bahasa Indonesia. Lebih-

$$
\begin{array}{ll}
\mathrm{Htl}=\text { hotel } & \text { Krn = koran } \\
\mathrm{Krm}=\text { kiriman } & \mathrm{Md}=\text { sabun mandi } \\
\mathrm{Mr}=\text { makanan ringan } & \mathrm{Ob}=\text { obat }
\end{array}
$$

lebih lagi, adanya kenyataan bahwa lafal bahasa Indonesia sebenarnya bervariasi begitu banyak variannya yang boleh dikatakan sebagai dialek atau logat. Tentu saja sulit sekali ditemui lafal baku sebagai representasi penggunaan bahasa baku dalam iklan karena situasi dan konteks komunikasi yang terdapat dalam iklan tidak menuntut penggunaan bahasa baku pada penuturnya.

Berikut ini disajikan contoh iklan yang menggunakan bahasa Indonesia secara keseluruhan (dengan diselipi unsur bahasa daerah). Contoh (1) iklan yang menggunakan iklan berbahasa Indonesia dengan logat Jakarta. Contoh (2) iklan yang menggunakan bahasa Indonesia secara keseluruhan (dengan diselipi unsur bahasa daerah).

(1) Contoh 1:

Kode : 166155STV

Iklan Bodrex

1. Dialog antarpenutur iklan

Perempuan 1: Ibu sakit kepala?

Laki-laki: Cepat minum bodrex!

Perempuan 2: Tapi belum makan.

Laki-laki: Itulah okenya bodrex. Dapat diminum sebelum makan.

Bersama-sama: Bodrex mengucapkan selamat berpuasa.

2. Narasi

"Seorang perempuan setengah tua yang mengikuti ceramah, tiba-tiba sakit kepala. Perempuan di sebelahnya menanyainya. Kemudian seorang ustadz memintanya untuk minum bodrex" 
3. Setting

Di teras rumah.

4. Tulisan dalam iklan

"Ahlinya Sakit Kepala"

"Dapat diminum sebelum makan"

(2) Contoh 2:

Kode : $1661810 S T V$

Iklan Rokok Djarum 76

1. Dialog antarpenutur iklan

Jin: "Kuberi satu permintaan."

Pemuda: "Satu aja? Tiga bisa?"

Jin:"Gampang."

Pemuda: "Caranya gimana?"

Jin: "Sakti...."

Pemuda: "Kok bisa sakti?"

Jin: "Dari sononya."

Pemuda: "Dari sono mana?"

Jin: "Dari nenek moyang."

Pemuda: "Moyangmu siapa? Kok nggak ikut? Ada pin bbnya?"

Jin: "Mulut apa [opo] knalpot bocor sih. Treng teng teng teng...."

Pemuda: "Eh, siapa bocor?"

Jin : "(menutup mulut pemuda itu dengan lakban) Mampetknalpote mampet."

2. Narasi

Seorang pemuda sedang jalan di taman. Ia menemukan lampu ajaib dan menendangnya. Tiba-tiba keluar seorang jin. Lalu jin tersebut mengajak bicara pemuda tersebut.

3. Setting

Di taman

4. Tulisan dalam iklan

Djarum 76 Filter Gold.Yang penting hepii.

Peringatan: merokok membunuhmu.

Banyak juga iklan mencampur penggunaan bahasa Indonesia dengan bahasa Inggris. Bila dilihat penggunaan bahasa dilihat dari perspektif lisan dan tulis penggunaan bahasa Indonesia dan bahasa Inggris dalam iklan dapat dikelompokkan menjadi empat kategori. Pertama, iklan yang menggunakan bahasa Indonesia lisan secara utuh disertai dengan bahasa Inggris dalam bentuk teks tulisan. Kedua, iklan menggunakan bahasa Inggris lisan secara utuh disertai dengan bahasa Indonesia dalam bentuk teks tulis. Ketiga, ada pula sebagian iklan yang menggunakan bahasa Inggris lisan secara utuh disertai dengan teks berbahasa Inggris, dan tulisan berbahasa Indonesia. Keempat, ada iklan yang menggunakan bahasa lisan dan tulisan campuran bahasa Indonesia dan Inggris. Berikut disajikan dua contoh iklan nomor (3) dan (4) untuk penggambaran penggunaan bahasa Indonesia dan bahasa Inggris tersebut.

Penggunaan bahasa Indonesia dalam iklan televisi di Indonesia tersebut sesuai dengan kebijakan politik bahasa nasional 
(3) Contoh 3:

Kode : $1661912 S T V$

Iklan Rokok LA Bold

1. Monolog

This is my kind of playground, my kind of party, my kind of game, my kind of music, my kind of dance. Bold is my kind of world. L.A. the bold new world.

2. Setting

Di kereta api, di kantor, di rumah, di jalan, di tempat olahraga, di atas gedung.

3. Tulisan

This is my kind of playground, my kind of party, my kind of game, my kind of music, my kind of dance. Bold is my kind of world. L.A. the bold new world.

Peringatan: merokok membunuhmu.

(4) Contoh 4:

Kode 167244STV

Iklan Mobil Swift (Suzuki)

1. Narasi

Seorang perempuan mengendarai mobil dengan cepat melintasi perkotaan di luar negeri.

2. Monolog

Let's go

3. Setting

Perkotaan.

4. Tulisan

Swift, brings the streets to life.

Suzuki, Way of Life.

yang tertuang dalam UU RI Nomor 24 Tahun 2009 Bab III pasal 25 ayat (3) terkait dengan fungsi bahasa Indonesia sebagai bahasa media massa dalam kedudukannya sebagai bahasa resmi negara. Hal tersebut dikuatkan dengan pasal 39 ayat (1) yang menyatakan bahwa bahasa Indonesia wajib digunakan dalam informasi melalui media massa. Bila iklan di dalamnya memuat informasi tentang produk barang atau jasa produksi dalam atau luar negeri yang beredar di Indonesia, kewajiban penggunaan bahasa Indonesia diatur dalam pasal 37 ayat (1).

Penggunaan bahasa Inggris sebagai bahasa asing yang berdampingan dengan bahasa Indonesia dengan pertimbangan tertentu sesuai dengan kebijakan politik bahasa nasional yang tertuang dalam pasal 37 ayat (2) yang menyatakan bahwa informasi dapat dilengkapi dengan bahasa asing sesuai dengan keperluan. Bila dikaitkan dengan kebijakan penggunaan bahasa di media massa, bahasa asing dapat digunakan untuk tujuan dan sasaran khusus.

Penggunaan bahasa Inggris yang sama sekali tidak terdapat penggunaan bahasa Indonesia bertentangan atau menyalahi kebijakan politik bahasa nasional terkait dengan fungsi bahasa Indonesia sebagai bahasa media massa dalam kedudukannya sebagai bahasa resmi negara (UU RI Nomor 24 Tahun 2009 Bab III pasal 37) bila iklan dipandang sebagai penyampaian tentang produk barang atau jasa produksi dalam atau luar negeri yang beredar di Indonesia. Namun, bila iklan dikaitkan 
dengan penggunaan bahasa dalam media massa, penggunaan bahasa Inggris saja --yang sama sekali tidak menggunakan bahasa Indonesia tersebut masih dapat ditoleransi oleh kebijakan politik bahasa nasional yang tertuang dalam UU RI Nomor 24 Tahun 2009 Bab III pasal 39 ayat (2) yaitu bila penggunaan bahasa tersebut mempunyai tujuan khusus atau sasaran khusus.

\section{Bentuk Lingual yang Digunakan dalam Iklan Televisi di Indonesia}

Bentuk-bentuk lingual yang ditemukan dalam sumber data yang berupa iklan ini adalah kalimat, frasa, dan kata. Ketiga bentuk lingual itu ditemukan baik dalam bahasa Indonesia maupun dalam bahasa Inggris. Bentuk lingual kata dan frasa ada yang berupa kata dan frasa bahasa Inggris, ada kata dan frasa bahasa Indonesia, dan ada yang berupa kata dan frasa campuran antara bahasa Inggris dengan bahasa Indonesia. Untuk selanjutnya, frasa dan kata dalam bahasa Indonesia tidak dihitung dalam penelitian ini karena frasa dan kata ditemukan dalam satuan lingual yang lebih besar, yakni kalimat. Demikian pula, kata dan frasa dalam bahasa Inggris yang berada dalam satuan lingual kalimat dalam bahasa Inggris tidak lagi dihitung sebagai kata atau frasa, dan kata yang terdapat dalam frasa tidak diperhitungkan sebagai kata. Satuan yang demikian itu akan dilihat sebagai satuan yang lebih besar, yakni kalimat atau frasa.

Bentuk lingual berupa kalimat dalam bahasa Indonesia ditemukan pada hampir seluruh iklan yang dipakai sebagai sumber data. Ada kalimat yang murni bahasa Indonesia saja (dengan campuran kata bahasa daerah atau dialek), ada yang dicampur atau diselipi dengan frasa atau kata bahasa Inggris, dan ada yang dicampur dengan kata atau frasa campuran antara bahasa Inggris dengan bahasa Indonesia. Kalimat bahasa Indonesia digunakan pada hampir seluruh iklan. Pernyataan tersebut didukung data kuantitatif. Secara kuantitatif dari 59 iklan terdapat 55 atau $93,22 \%$ persen yang menggunakan kalimat bahasa Indonesia, yang dapat muncul dalam bentuk tulisan atau lisan karena terdapat 4 iklan yang tidak menggunakan bahasa Indonesia baik lisan maupun tulisan.

Penggunaan bahasa Inggris yang wujud lingualnya dapat berupa kalimat, frasa, dan atau kata di samping bahasa Indonesia tersebut merupakan konsekuensi dari adanya kontak bahasa. Persoalan mengapa bahasa Inggris yang menjadi "sandingan" atau pendamping bahasa Indonesia dalam iklan televisi di Indonesia kiranya perlu dianalis. Secara sosiolinguistik kiranya dapat dimaklumi mengingat bahasa Inggris merupakan bahasa internasional yang memiliki prestise tinggi. Bahkan, prestise bahasa Indonesia bagi orang Indonesia berada di bawah bahasa Inggris, dan rasa bahasa Indonesia berada di atas bahasa daerah. Selain itu, sikap positif belum dimiliki oleh sebagian penutur Indonesia. Sementara itu, bila dilihat dari tingkat emosi dan keakraban bahasa dengan penuturnya, bahasa Indonesia berada di bawah bahasa daerah dan bagi sebagian yang lain berada di bawah bahasa Inggris. Artinya posisi bahasa Indonesia secara emosi dan keakraban berada di paling bahwah di antara bahasa daerah dan bahasa Inggris (Chaer dan Agustina, 2010; Moeliono, 2011; Silado, 2011; Haryanto, 2014; dan Setyaningsih, 2014).

\section{Kaitan Antara Bahasa dengan Sasaran Iklan Televisi di Indonesia}

Sebagian besar iklan televisi di Indonesia diarahkan pada tingkat sosial atau kalangan umum. Sedikit sekali iklan yang diarahkan pada pangsa pasar berstatus sosial tinggi. Iklan yang diarahkan pada masyarakat berstatus sosial rendah tidak dijumpai sama sekali. Pada umumnya iklan dengan sasaran masyarakat umum 
disampaikan dengan bahasa Indonesia bercampur dengan bahasa Inggris. Hal tersebut didukung oleh data kuantitatif sebanyak $52(88,14 \%)$ iklan dari 59 iklan. Sementara itu, dari 52 iklan tersebut yang menggunakan bahasa Indonesia saja hanya 22 iklan. Penggunaan unsur bahasa Inggris pada iklan dengan sasaran umum cukup kuat. Hal tersebut ditunjukkan data secara kuantitatif sebanyak 30 (50,85\%) iklan. Iklan sebanyak 30 iklan tersebut bilan dibanding dengan 52 iklan yang menggunakan bahasa Indonesia telah mencapai 57,69\%. Hal itulah yang memberikan kesan bahwa pada iklan dengan sasaran kalangan umum penggunaan unsur bahasa Inggris cukup kuat. Hal tersebut sejalan dengan dengan uraian tentang penggunaan bahasa dalam iklan di atas bahwa bahasa Indonesia masih memiliki posisi dominan, dan bahasa Inggris cukup dominan mempengaruhi penggunaan bahasa Indonesia.

Bahasa Inggris dan bahasa Inggris campur bahasa Indonesia cenderung digunakan pada iklan televisi dengan sasaran kelas tinggi. Hal itu didukung oleh data kuantitatif bahwa dari tujuh iklan dengan sasaran masyarakat kelas tinggi empat di antaranya menggunakan bahasa Inggris saja, dan tiga lainnya menggunakan bahasa Inggris campur bahasa Indonesia, serta tidak ada satu pun yang hanya menggunakan bahasa Indonesia. Penggunaan bahasa Inggris saja pada iklan dengan sasaran kelas umum tidak ditemukan. Hal inilah yang menguatkan bahwa bahasa Inggris cenderung digunakan dalam iklan dengan sasaran masyarakat kelas sosial tinggi.

\section{Kaitan Bahasa dengan Jenis Iklan Tele- visi di Indonesia}

Kaitan antara penggunaan bahasa dengan jenis iklan terdapat tiga butir. Pertama, pada umumnya bahasa Indonesia digunakan pada jenis iklan televisi di Indonesia tersebut baik bahasa Indonesia "murni" maupun dengan campuran bahasa Inggris. Hal tersebut sesuai dengan kebijakan politik bahasa nasional yang tertuang dalam UU RI Nomor 24 Tahun 2009 Bab III pasal 25 ayat (3) dan dikuatkan dengan pasal 39 ayat (1) terkait dengan informasi melalui media massa, serta pasal 37 ayat (1) terkait dengan informasi produk barang atau jasa produksi dalam atau luar negeri yang beredar di Indonesia (bandingkan juga dengan halaman 30). Secara kuantitatif pernyataan ini didukung dengan data penggunaan bahasa Indonesia pada jenis iklan, yaitu $22(37,29 \%)$ iklan, dan campuran dengan bahasa Inggris $33(55,93 \%)$ iklan, serta bila keduanya dijumlah terdapat $55(93,22 \%)$ iklan.

Kedua, penggunaan bahasa Inggris secara khusus ditemukan pada iklan produk tertentu, seperti rokok dan mobil. Penggunaan bahasa Inggris ini memang terkait dengan produk yang bersifat khusus pula, apalagi bila dicoba dikaitkan dengan sasaran produk tersebut. Jadi, produk tersebut memang dipasarkan untuk kalangan tertentu. Dengan demikian, kekhasan produk terkait dengan pilihan bahasa iklan terkait pula dengan pangsa atau sasaran pasarnya. Dengan perspektif ini dapat dipahami pilihan penggunaan bahasa Inggris terkait dengan jenis iklan tersebut. Bagaimana kaitannya dengan kebijkan politik bahasa, kiranya sejalan dengan pembahasan penggunaan bahasa yang sudah disajikan di depan.

Ketiga, pengunaan bahasa campuran antara bahasa Indonesian dan bahasa Inggris cenderung lebih banyak atau lazim digunakan oleh jenis iklan. Hal itu sebagai konsekuensi terjadinya kontak bahasa, sehingga bahasa Indonesia banyak terpengaruh oleh bahasa Inggris. Bila dirunut lebih lanjut ternyata penggunaan bahasa Inggris tersebut berupa kata atau frase sehingga pada prinsipnya tetap dapat dipandang sebagaiiklan berbehasa Indonesia. Iklan yang banyak mengandung unsur bahasa Inggris ini antara lain 
iklan sabun muka, sampo, mobil, obat, dan rokok. Secara kuantitatif iklan yang menggunakan bahasa campuran tersebut mencapai 33 (55,93\%) iklan.

Data kuantitatif memperkuat kondisi pemakaian bahasa yang berhubungan dengan sikap bahasa penutur ini ditangkap oleh pembuat iklan sebagai bagian yang layak untuk disajikan (dikonsumsikan). Oleh karena itu, menjadi sebuah kewajaran ketika dalam iklan muncul banyak sekali bahasa asing. Hal ini banyak ditemukan dalam jenis iklan yang bila dirunut sasarannya adalah kalangan muda usia atau kelas sosial umum dan atas. Misalnya pada jenis iklan mobil, iklan perumahan, dan iklan jasa. Ketiga iklan ini memang ditujukan untuk kalangan tinggi, baik secara ekonomi maupun pendidikan. Jadi, dalam penyajiannya juga diselaraskan dengan kebutuhan akan prestise. Penggunaan bahasa sebagai salah satu perwujudan nilai prestise di masyarakat. Bahasa asing dianggap lebih bergensi dibandingkan bahasa Indonesia. Dengan demikian, wujud iklannya juga diwarnai dengan unsur asing untuk menunjukan faktor prestise dari pemiliknya.

Penggunaan bahasa yang diwarnai dengan unsur dari bahasa asing banyak ditemukan pada iklan mobil. Hal ini bisa dimengerti bahwa sasaran iklan mobil adalah kalangan atas yang telah disajikan pada contoh iklan (3) dan (4) dapat dilihat iklan mobil di atas. yang semuanya terdapat warna bahasa Inggris.

\section{Kaitan Bentuk Lingual dengan Sasaran Iklan Televisi di Indonesia}

Kaitan (hubungan) bentuk lingual dengan sasaran iklan televisi di Indonesia dapat disajikan berikut ini. Kalimat bahasa Indonesia merupakan wujud lingual yang lazim muncul atau digunakan dalam iklan televisi di Indonesia untuk semua sasaran, baik secara sosial maupun umur. Tentu saja hal itu sejalan dengan penggunaan bahasanya, yaitu pada umumnya menggunakan bahasa Indonesia. Hal itu didukung data kuantitatif sebagai berikut. Dari 59 buah iklan, 55 (93,22\%) iklan di antaranya menggunakan bahasa Indonesia untuk semua sasaran, dengan rincian $50(84,75 \%)$ iklan sasaran sosial umum dan $47(79,66 \%)$ sasaran usia umum; $5(8,47 \%)$ iklan sasaran sosial tinggi dan $8(13,56 \%)$ iklan sasaran usia muda.

Selain penggunaan kalimat bahasa Indonesia, terdapat kecenderunggan penggunaan kalimat bahasa Inggris pada iklan dengan sasaran kelas sosial tinggi dan usia muda. Bila dikaitkan secara silang penggunaan kalimat bahasa Inggris dengan sasaran usia dan sosial, dapat dinyatakan bahwa kalimat bahasa Inggris digunakan pada iklan yang memiliki sasaran usia umum yang berstatus sosial tinggi. Hal itu didukung oleh data kuantitatif sebagai berikut. Dari 8 (13,56\%) iklan yang menggunakan kalimat berbahasa Inggris, $7(11,86 \%)$ iklan sasaran berstatus sosial tinggi dan 1 (1,69\%) iklan sasaran berstatus sosial umum, yang berarti juga untuk kelas sosial tinggi termasuk di dalamnya. Bila keduanya dibandingkan, 7 berbanding 1 atau proporsi $87,50 \%$ sasaran kelas sosial tinggi dan $12,50 \%$ sasaran kelas sosial umum. Perlu disampaikan bahwa dari 8 iklan menggunakan kalimat bahasa Inggris tersebut 4 di antaranya menggunakan (kalimat) bahasa Inggris tanpa ada penggunaan bahasa Indonesia, sisanya menggunakan kalimat Inggris dan kalimat Indonesia. Sementara itu, pengguaan kalimat bahasa Inggris untuk sasaran usia muda terdapat 2 (3,39\%), dan sisasnya untuk usia umum yang berarti untuk sasaran usia muda juga.

Dengan ilustrasi singkat ini kiranya dapat dipahami bahwa kalimat bahasa Inggris digunakan iklan televisi di Indonesia cenderung terjadi pada sasaran sosial tinggi dan usia muda. Iklan dengan sasaran usia umum (tua dan muda) dapat diduga termasuk ke dalam sasaran sosial tinggi. Hal tersebut terkait dengan 
masalah prestise dan sikap berbahasa. Bahasa Inggris dipadang memiliki prestise yang tinggi, kelas sosial tinggi juga memiliki prestise yang tinggi. Dengan begitu, pembuat iklan menyadari akan sikap tersebut dan akhirnya berimbas pada sikap pemilihan bahasa pembuat iklan, yaitu memilih menggunakan kalimat bahasa Inggris untuk iklan dengana sasaraan kelas sosial tinggi dan usia muda.

Penggunaan frasa dan kata bahasa Inggris muncul sebagai selipan dalam iklan televisi Indonesia berbahasa Indonesia dengan sasaran kelas sosial umum dan usia umum. Hal itu ditunjukkan pula oleh data kuantitatif sebagai berikut. Frasa yang digunakan dalam iklan sasaran kelas sosial tinggi 3 (5.08\%) iklan dan sasaran kelas sosial umum 14 (23,73\%) iklan, kata yang digunakan dalam iklan dengan sasaran kelas sosial tinggi 3 (5.08\%) iklan dan sasaran kelas sosial umum 15 (25,42\%) iklan. Frasa yang digunakan dalam iklan sasaran kelas usia muda $2(3,39 \%)$ iklan dan sasaran kelas usia umum 15 (25,42\%) iklan, kata yang digunakan dalam iklan dengan sasaran kelas usia muda $5(8,47 \%)$ iklan dan sasaran kelas usia umum 13 $(22,51 \%)$ iklan. Data tersebut menggambarkan kuatnya "peminjaman" kosakata bahasa Inggris dalam bahasa Indonesia. Contoh penggunaan bahasa Inggris yang diselipkan dalam iklan berbahasa Indonesia, antara lain penggunaan a member alam sutera, You kan tahu sebagai bos, I harus punya hunian yang bergengsi. Ini ...membuat $I$ pusing tujuh keliling. You tahu ... yang terdapat dalam contoh iklan (11). Contoh lain dapat dilihat dalam lampiran.

\section{SIMPULAN}

Berdasarkan uraian hasil penelitian dan pembahasan yang telah disajikan di atas, temuan kajian tentang pemakaian bahasa dalam iklan televisi di Indonesia dengan judul "Eksistensi Bahasa dalam Iklan Indonesia: Studi Kontak Bahasa" ini secara singkat dapat dirangkum sebagai perikut.

Pertama, bahasa yang digunakan dalam iklan televisi di Indonesia dapat dikelompokan menjadi dua, yaitu bahasa Indonesia dan bahasa Inggris. Bahasa Indonesia dalam penelitian ini meliputi bahasa Indonesia dialek Jakarta -yang paling menonjol, dan daerah, serta bahasa daerah. Dalam kenyataan terjadi pencampuran penggunaan bahasa Indonesia dengan bahasa Inggris yang menunjukkan terjadinya kontak bahasa antara bahasa Indonesia dengan bahasa Inggris. Secara umum bahasa Indonesia digunakan dalam iklan televisi di Indonesia dengan campur bahasa Inggris.

Kedua, bentuk lingual yang digunakan dalam iklan televisi di Indonesia dapat dikelompokkan menjadi (1) kalimat bahasa Indonesia, (2) kalimat bahasa Inggris, (3) frase bahasa Inggris, dan (4) kata bahasa Inggris.

Ketiga, kaitan antara penggunaan bahasa dengan sasaran iklan televisi di Indonesia berupa (1) bahasa Indonesia dan campuran bahasa Indonesia dengan bahasa Inggris cenderung digunakan dalam iklan dengan sasaran sosial dan usia umum, dan (2) bahasa Inggris digunakan untuk sasaran kelas sosial tinggi dan usia muda.

Keempat, terdapat kaitan bahasa dengan jenis iklan. Bahasa Indonesia digunakan pada Iklan produk/jasa pada umumnya, dan bahasa Inggris digunakan pada iklan produk/jasa tertentu. Iklan produk/ jasa tertentu tersebut bila dirunut terkait dengan sasaran iklannya. Iklan produk barang "mewah" dengan sasaran sosial tinggi dan usia muda cenderung menggunakan bahasa Inggris.

Kelima, terdapat kaitan bentuk lingual atau bentuk bahasa dengan sasaran iklan. Kalimat bahasa Indonesia digunakan pada iklan dengan sasaran umum, baik dilihat dari kelas sosial maupun usia. Kalimat bahasa Inggris cenderung digunakan 
dalam iklan dengan sasaran kelas sosial tinggi dan usia muda. Hal itu terkait dengan persoalan prestise dan sikap pembuat iklan. Karena bahasa Inggris memiliki prestise tinggi, masyarakat kelas sosial tinggi tentunya juga berprestise tinggi sehingga pembuat iklan mengambil sikap memilih bahasa Inggris sebagai media iklannya.

\section{UCAPAN TERIMA KASIH}

Artikel ini diangkat dari laporan hasil penelitian yang dibiayai oleh dana anggaran DIPA UNY tahun 2016 alokasi FBS. Oleh karena ittu, ucapan terima kasih disampaikan kepada BPP FBS UNY yang telah menyelenggarakan seminar proposal dan hasil penelitian. Ucapan terima kasih disampaikan pula pada reviewer dan redaksi yang telah membaca, mengoreksi, dan memberikan masukan terhadap artikel ini.

\section{DAFTAR PUSTAKA}

Alwi, Hasan dan Dendy Sugono. 2011. Politik Bahasa. Jakarta: Badan Pengembngan dan Pembinaan Bahasa Kemendikbud.

Chaer, Abdul dan Leonie Agustina. 2010. Sosiolinguistik: Perkenalan Awal. Jakarta: Rineka Cipta.

Haryanto, Prima. 2014. “Kedwibahasaan dalam Junior Masterchef Indonesia Musim pertama: Kajian Sosiolinguistik" dalam Pendidikan Berbasis Budaya: Sumbangan Bahasa dan Sastra. (Prosiding Seminar Internasional) Jakarta: Fakultas Ilmu Tarbiyah dan Keguruan UIN Syarif Hidayatullah Jakarta.

Hickey, Raymond. 2013. The Handbook of Language Contact. Oxford: WileyBlackwell.

Hudson, R.A. 2000. Sociolinguistics. Cambridge: Cambridge University Press.

Listyaningrum, Desy. 2014. “Gejala Dominasi Bahasa Jawa terhadap Leksikon Bahasa Indonesia (Perspektif Politik Bahasa)" dalam Pendidikan Berbasis Budaya: Sumbangan Bahasa dan Sas- tra. (Prosiding Seminar Internasional) Jakarta: Fakultas Ilmu Tarbiyah dan Keguruan UIN Syarif Hidayatullah Jakarta.

Matras, Yoron. 2009. Language Contact. Cabridge: Cambridge University Press.

Moeliono, Anton M. 1980. Bahasa Indonesia dan Ragamnya. Jakarta: Pusat Pembinaan dan Pengembangan Bahasa.

Moeliono, Anton M. 2011. "Kebijakan Bahasa dan Perencanaan Bahasa Indonesia: Kendala dan Tantangan" dalam Perencanaan Bahasa pada bAbad ke-21: Kendala dan Tantangan (Penyunting Sugiyono dan Yeyen Maryani). Jakarta: Badan Pengembangan dan Pembinaan Bahasa Kemendikbud.

Muslih, Mansur. 2010. Bahasa Indonesia pada Era Globalisasi. Jakarta: Bumi Aksara.

Silado, Remy. 2011. "Penyakit Menular Sok-Inggris dalam Bahasa Indonesia", dalam Pemberdayaan Bahasa Indonesia Memperkukuh Budaya Bangsa dalam Era Globalisasi (Penyunting Yeyen Maryani dan S.R.H. Sitanggang). Jakarta: Badan Pengembangan dan Pembinaan Bahasa Kemendikbud.

Thomason, Sarah G. 2001. Language Contact. Eidenburg: Eidenburg University Press.

UURI Nomor 24 Tahun 2009 Tentang Bendera, Bahasa, dan Lambang Negara, serta Lagu Kebangsaan. Jakarta: Badan Pengembangandan Pembinaan Bahasa Kemendikbud.

Wardhaugh,Ronald. 1998. An Introduction to Sociolinguistics. Oxford: Blackwell.

Widada Hs. 2011. "Reaktualisasi Peran Bahasa Indonesia dalam Konteks Lokal dan Global" dalam Pemberdayaan Bahasa Indonesia Memperkukuh Budaya Bangsa dalam Era Globalisasi (Penyunting Yeyen Maryani dan S.R.H. Sitanggang). Jakarta: Badan Pengembangan dan Pembinaan Bahasa Kemendikbud. 


\section{Lampiran: Data Kuantitatif Bahasa dalam Iklan Televisi di Indonesia}

Tabel 2. Distribusi Penggunaan Bahasa dalam Iklan di Televisi

\begin{tabular}{llrc}
\hline No & Bahasa yang digunakan & Iklan & Persentase \\
\hline 1 & Bahasa Indonesia saja & 22 & 37,29 \\
2 & Bahasa Indonesia dicampur unsur bahasa Inggris & 33 & 55,93 \\
3 & Bahasa Inggris saja & 4 & 6,78 \\
4 & Bahasa Indonesia (kumulatif nomor 1 dan 2) & 55 & 93,22 \\
5 & Bahasa Inggris (kumulatif nomor 2 dan 3) & 37 & 62,71 \\
\hline
\end{tabular}

Tabel 3. Distribusi Bentuk-bentuk lingual dalam Iklan di Televisi

\begin{tabular}{clcr}
\hline No & \multicolumn{1}{c}{ Bentuk Lingual } & Jumlah Iklan & Persentase \\
\hline 1 & Kalimat dalam bahasa Indonesia & 56 & $93,22 \%$ \\
2 & Kalimat dalam bahasa Inggris & 8 & $13,56 \%$ \\
3 & Frasa dalam bahasa Inggris & 17 & $28,81 \%$ \\
4 & Kata dalam bahasa Inggris & 13 & $22,03 \%$ \\
5 & Frasa dan kata campuran bahasa & 3 & $5,08 \%$ \\
& Indonesia dan Inggris & & \\
\hline
\end{tabular}

Tabel 4. Hubungan antara penggunaan bahasa iklan dengan sasaran iklan

\begin{tabular}{|c|c|c|c|c|c|c|c|c|c|c|c|}
\hline \multirow{3}{*}{\multicolumn{2}{|c|}{ Sasaran Iklan }} & \multicolumn{10}{|c|}{ Penggunaan Bahasa } \\
\hline & & \multicolumn{2}{|c|}{$\begin{array}{c}\text { Indonesia } \\
\text { saja (1) }\end{array}$} & \multicolumn{2}{|c|}{$\begin{array}{c}\text { Indonesia \& } \\
\text { Inggris (2) }\end{array}$} & \multicolumn{2}{|c|}{$\begin{array}{l}\text { Inggris saja } \\
\text { (3) }\end{array}$} & \multicolumn{2}{|c|}{$\begin{array}{l}\text { Gabungan } \\
\text { (1) dan (2) }\end{array}$} & \multicolumn{2}{|c|}{$\begin{array}{l}\text { Gabungan } \\
\text { (2) dan (3) }\end{array}$} \\
\hline & & Juml & Persen & Juml & Persen & Juml & Persen & Juml & Persen & Juml & Persen \\
\hline \multirow{3}{*}{ Sosial } & $\mathrm{Tg}$ & & & 3 & 5.08 & 4 & 6,78 & 3 & 5.08 & 7 & 11,86 \\
\hline & $\mathrm{Rd}$ & - & - & - & - & - & - & - & - & - & - \\
\hline & $\mathrm{Um}$ & 22 & 37,29 & 30 & 50,85 & - & - & 52 & 88.14 & 30 & 50,85 \\
\hline \multicolumn{2}{|c|}{ Jumlah } & 22 & 37,29 & 33 & 55,93 & 4 & 6,78 & 55 & 93,22 & 37 & 62,71 \\
\hline \multirow{3}{*}{ Usia } & $\mathrm{Tu}$ & - & - & - & - & - & - & - & - & - & - \\
\hline & $\mathrm{Mu}$ & 2 & 3,39 & 6 & 10,17 & 1 & 1,69 & 8 & 13,56 & 7 & 11,86 \\
\hline & $\mathrm{Um}$ & 20 & 33,90 & 27 & 45,76 & 3 & 5.08 & 47 & 79,66 & 30 & 50,85 \\
\hline \multicolumn{2}{|c|}{ Jumlah } & 22 & 37,29 & 33 & 55,93 & 4 & 6,78 & 55 & 93,22 & 37 & 62,71 \\
\hline
\end{tabular}


Tabel 5. Keterkaitan antara Penggunaan Bahasa dengan Jenis Iklan

\begin{tabular}{|c|c|c|c|c|c|c|c|c|c|c|c|c|}
\hline \multirow[t]{2}{*}{ No } & \multirow{2}{*}{$\begin{array}{c}\text { Nama } \\
\text { Produk/jasa }\end{array}$} & \multicolumn{3}{|c|}{ Sasaran } & \multicolumn{3}{|c|}{ Jumlah } & \multicolumn{3}{|c|}{ Persentase } & \multicolumn{2}{|c|}{ Bahasa } \\
\hline & & $\mathrm{Tg}$ & $\mathrm{Rd}$ & Um & $\mathrm{Tg}$ & $\mathrm{Rd}$ & $\mathrm{Um}$ & $\mathrm{Tg}$ & $\mathrm{Rd}$ & Um & Ind & $\mathrm{Ig}$ \\
\hline 1. & Mobil & $\mathrm{V}$ & & & 6 & & & 10,1 & & & & $\mathrm{~V}$ \\
\hline 2. & Rokok & V & & V & 1 & & 3 & 1,6 & 5, & & V & \\
\hline 3. & Jasa & $\mathrm{V}$ & & & 3 & & & 5,05 & & & & V \\
\hline 4. & Perumahan & V & & & 1 & & & 1,6 & & & & $\mathrm{~V}$ \\
\hline 5. & Shampoo & & & V & & & 5 & & & 8,4 & V & \\
\hline 6. & Minuman & & & V & & & 5 & & & 8,4 & V & \\
\hline 7. & Makanan & & & V & & & 5 & & & 8,4 & V & \\
\hline 8. & $\begin{array}{l}\text { Ringan } \\
\text { Pembersih } \\
\text { Pakaian }\end{array}$ & & & V & & & 5 & & & 8,4 & V & \\
\hline 9. & Obat & & & V & & & 5 & & & 8,4 & V & \\
\hline 10. & Koran & & & V & & & 1 & & & 1,6 & V & \\
\hline 11. & Mie & & & V & & & 5 & & & 8,4 & V & \\
\hline 12. & Sabun Muka & & & V & & & 5 & & & 8,4 & V & \\
\hline 13. & Sabun Mandi & & & V & & & 6 & & & 10,1 & $\mathrm{~V}$ & \\
\hline
\end{tabular}

Tabel 6. Hubungan antara bentuk lingual bahasa iklan dengan sasaran iklan

\begin{tabular}{|c|c|c|c|c|c|c|c|c|c|c|c|}
\hline \multirow{3}{*}{ Sasaran } & \multirow{3}{*}{ Iklan } & \multicolumn{10}{|c|}{ Penggunaan Bahasa } \\
\hline & & \multicolumn{2}{|c|}{$\begin{array}{c}\text { Kalimat } \\
\text { bahasa } \\
\text { Indonesia }\end{array}$} & \multicolumn{2}{|c|}{$\begin{array}{l}\text { Kalimat } \\
\text { bahasa } \\
\text { Inggris }\end{array}$} & \multicolumn{2}{|c|}{$\begin{array}{c}\text { Frasa } \\
\text { Bahasa } \\
\text { Inggris }\end{array}$} & \multicolumn{2}{|c|}{$\begin{array}{c}\text { Kata Bahasa } \\
\text { Inggris }\end{array}$} & \multicolumn{2}{|c|}{$\begin{array}{c}\text { Campuran } \\
\text { Indonesia } \\
\text { dan Inggris }\end{array}$} \\
\hline & & Juml & Persen & Juml & Persen & Juml & Persen & Juml & Persen & Juml & Persen \\
\hline \multirow{3}{*}{ Sosial } & $\mathrm{Tg}$ & 5 & 8.47 & 7 & 11,86 & 3 & 5,078 & 3 & 5,078 & 2 & 3.39 \\
\hline & $\mathrm{Rd}$ & - & - & - & - & - & - & - & - & - & - \\
\hline & Um & 50 & 84.75 & 1 & 1,69 & 14 & 23.73 & 15 & 25,42 & 1 & 1,69 \\
\hline \multicolumn{2}{|c|}{ Jumlah } & 55 & 93.22 & 8 & 13,56 & 17 & 28,81 & 18 & 30,51 & 3 & 5,078 \\
\hline \multirow{3}{*}{ Usia } & $\mathrm{Tu}$ & - & - & - & - & - & - & - & - & -- & - \\
\hline & $\mathrm{Mu}$ & 8 & 13,56 & 2 & 3.39 & 2 & 3.39 & 5 & 8.47 & - & - \\
\hline & Um & 47 & 79,66 & 6 & 10,17 & 15 & 25,42 & 13 & 22,03 & 3 & 5,078 \\
\hline \multicolumn{2}{|l|}{ Jumlah } & 55 & 93.22 & 8 & 13,56 & 17 & 28,81 & 18 & 30,51 & 3 & 5,078 \\
\hline
\end{tabular}

